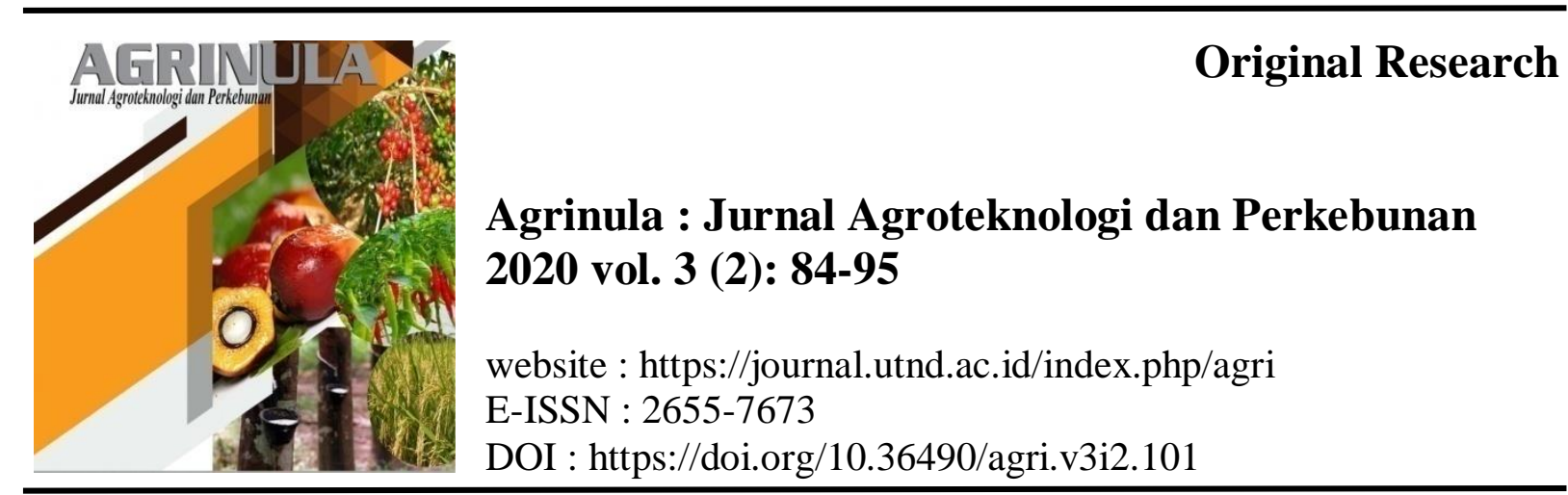

PEMANFAATAN KOMPOS BAGASE TEBU DAN EFEKTIFITAS PENGGUNAAN PUPUK $N$ TERHADAP PERTUMBUHAN VEGETATIF KAKAO (Theobroma cacao L.)

\title{
THE APPLICATION OF SUGARCANE BAGASSE COMPOST AND EFFECTIVENESS OF N-FERTILIZER ON VEGETATIVE GROWTH FOR COCOA (Theobroma cacao L.)
}

Muhammad Firmansayah ${ }^{1}$, Erfan Wahyudi ${ }^{*}$, Irwan Agusnu Putra ${ }^{2}$, \& Dedi Kurniawan ${ }^{2}$

${ }^{1}$ Program Studi Budidaya Perkebunan, Fakultas Pertanian dan Peternakan, Universitas Tjut Nyak Dhien, Medan 20123, Sumatera Utara, Indonesia

${ }^{2}$ Program Studi Agroteknologi, Fakultas Pertanian dan Peternakan, Universitas Tjut Nyak Dhien, Medan 20123, Sumatera Utara, Indonesia

*Koresponding author: erfan.wahyudi1@gmail.com

\begin{tabular}{|c|c|}
\hline Info & ABSTRAK \\
\hline $\begin{array}{l}\text { Disubmit: } \\
03 \text { Oktober } 2020 \\
\text { Direvisi: } \\
\text { 16 Oktober } 2020 \\
\text { Diterima: } \\
\text { 17 Oktober } 2020 \\
\text { Dipublikasi: } \\
\text { 17 Oktober } 2020\end{array}$ & 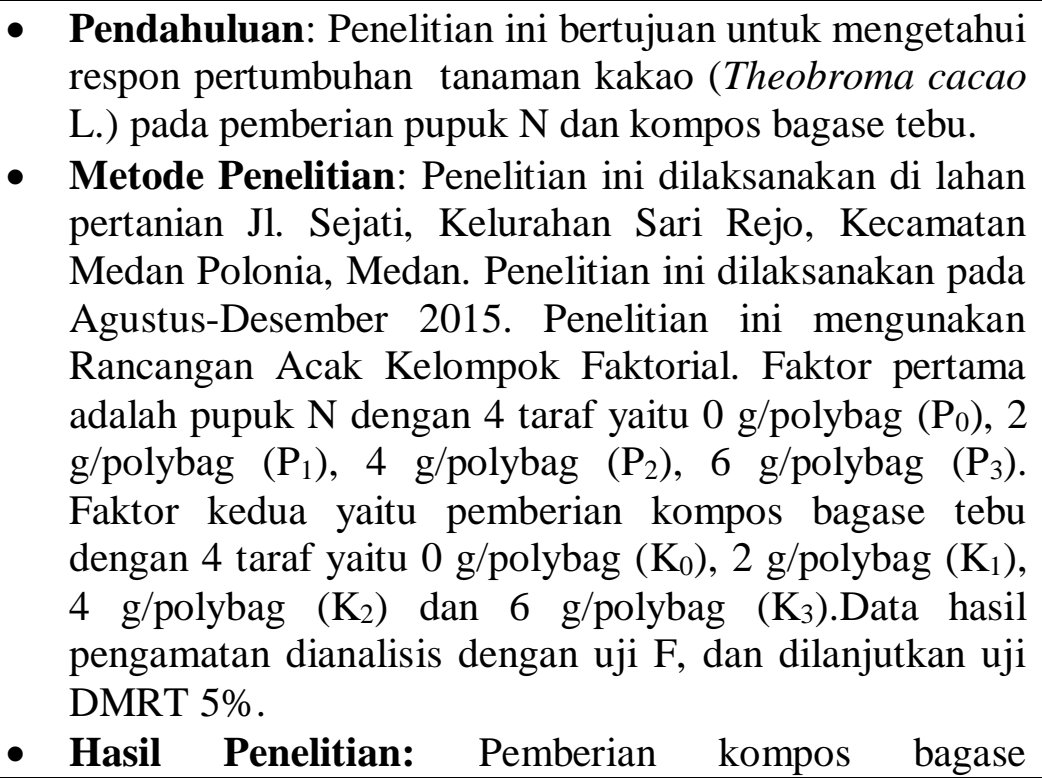 \\
\hline
\end{tabular}




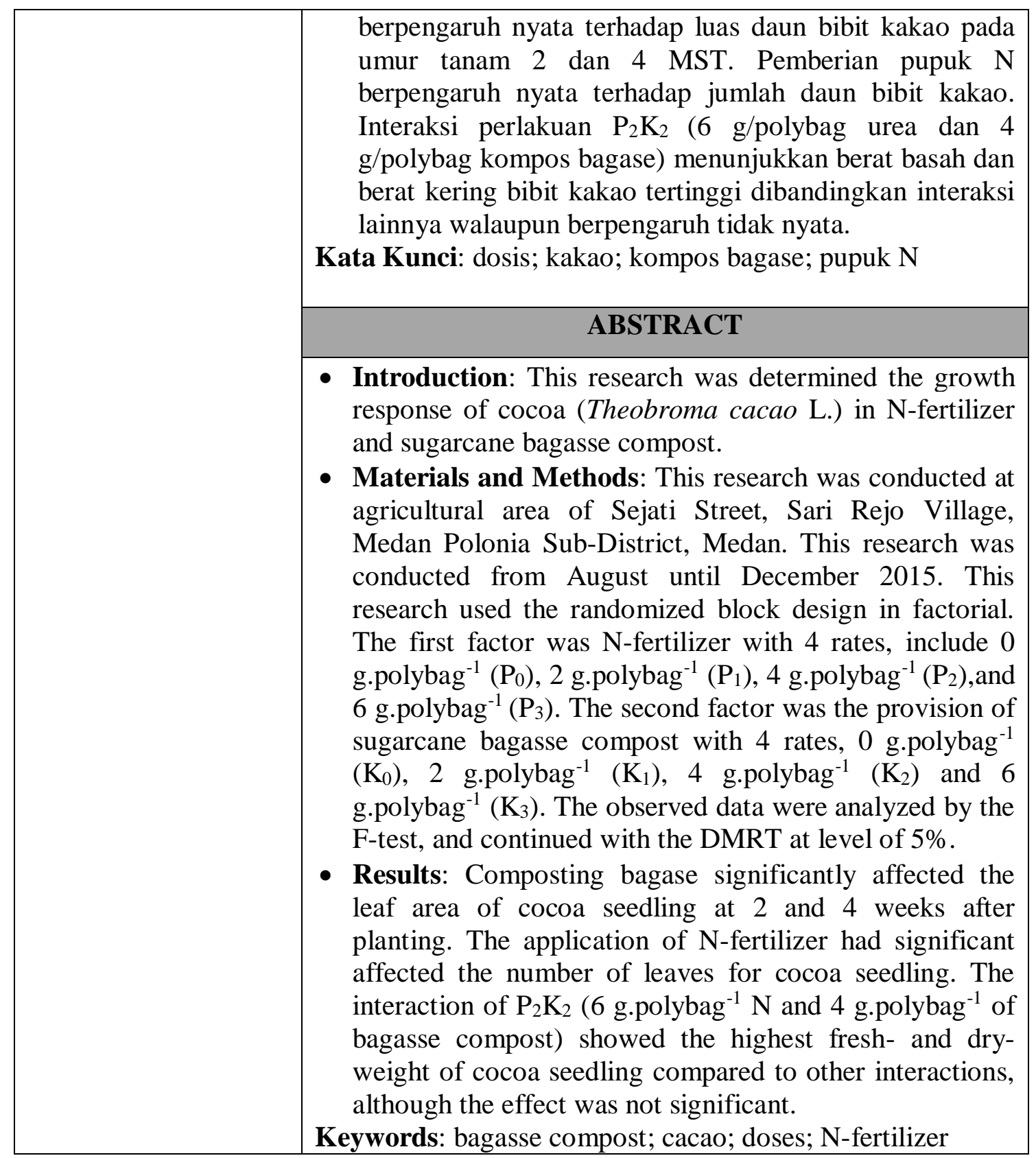

\section{PENDAHULUAN}

Kakao (Theobroma cacao L.) adalah salah satu komoditas unggulan sub sektor perkebunan. Komoditi kakao secara konsisten berperan sebagai sumber devisa negara yang memberikan kontribusi penting dalam perekonomian Indonesia (Arsyad et al., 2011). Sampai tahun 2015 luas areal kakao telah mencapai 1.724 .092 ha dengan produksi 661.243 ton (Direktorat Jenderal Perkebunan, 2015).

Aspek penting dalam budidaya tanaman kakao adalah penyediaan bahan tanam dalam pembibitan, karena dari pembibitan akan didapatkan bahan tanam yang cocok untuk ditanam di lapangan (Dalimunthe et al., 2015). Marum et al., (2012) melaporkan bahwa hasil samping industri gula di Indonesia berupa ampas (bagasse) sebesar 47,77\% dan masih memiliki kandungan air 48-52\%. Ampas tebu dapat diaplikasikan ke 
tanaman apabila telah dilakukan proses dekomposisi dengan bantuan bioaktivator yang bisa digunakan berasal dari Effective Mikroorganism 4 (EM-4).

Pupuk nitrogen merupakan pupuk yang dibutuhkan oleh tanaman untuk meningkatkan produktivitas dan mutu hasil (Rosmarkam \& Yuwono, 2002). Pemberian nitrogen dapat mempercepat pertumbuhan bagian vegetatif tanaman, memperbanyak butir-butir hijau daun, menciptakan perakaran yang kuat dan lebat. Kekurangan nitrogen akan menurunkan aktivitas metabolisme tanaman yang dapat menimbulkan klorosis. Menurut Musnamar, (2003) penggunaan pupuk organik yang dipadukan dengan penggunaan pupuk kimia dapat meningkatkan produktivitas tanaman dan pengurangan penggunaan pupuk kimia, baik dilahan sawah maupun di lahan kering.

Tujuan penelitian ini untuk mengetahui pemanfaatan kompos bagase tebu dan efektifitas penggunaan pupuk $\mathrm{N}$ terhadap pertumbuhan vegetatif tanaman kakao (Theobroma cacao L).

\section{BAHAN DAN METODE}

\section{Tempat dan Waktu Penelitian}

Penelitian dilaksanakan di lahan pertanian Kelurahan Sari Rejo, Kecamatan Medan Polonia, Medan pada bulan Juni - Desember 2015. Analisis tanah awal dilakukan di Laboratorium Fakultas Pertanian, UISU, Medan.

\section{Persiapan Lahan dan Analisis Tanah Awal}

Lahan area penelitian dibersihkan dari gulma dan tanaman lainnya kemudian dibuat petak-petak percobaan berukuran $60 \mathrm{~cm}$ x $60 \mathrm{~cm}$. Lahan penelitian diberikan atau dibuat naungan sesuai dengan standard pembuatan naungan di pembibitan Setiap percobaan dalam satu plot dibatasi oleh drainase selebar $50 \mathrm{~cm}$, sedangkan jarak antar ulangan percobaan selebar $100 \mathrm{~cm}$. Topsoil yang digunakan sebagai media tanam terlebih dahulu dianalisis beberapa karakteristik kimia tanah. Diperoleh analisis $\mathrm{N}$ sebesar 0,13\% (rendah), $\mathrm{P}_{2} \mathrm{O}_{5}$ dengan metode Bray-II sebsear 17,81 ppm (sangat tinggi), pH tanah dengan metode $\mathrm{H}_{2} \mathrm{O}$ sebesar 5,57 (agak masam), C-organik sebesar 1,23\% (rendah), K-dd dan Ca-dd masing-masing sebesar 0,11 (rendah) dan 4,31 (rendah).

\section{Pembuatan Kompos Bagase Tebu}

Dicacah ampas tebu untukmemperkecil ukuran partikel agarpengomposan berlangsung lebihcepat, kemudian disemprotkan dekomposer EM-4secara merata dan diinkubasi selama 4 minggu sampai mengalami perubahan bentuk.

\section{Persiapan Bahan Tanam dan Penyemaian}

Persiapan bahan dan lahan dilakukan dengan cara mengambil benih dari buah yang normal bentuknya, sehat dan cukup tua (masak atau matang di pohon) yang biasannya ditandai dengan warna buahnya kuning. Seleksi biji dilakukan dengan memilih 2/3 yang terletak pada bagian tengah, biji tersebut dipilih pada bentuk yang relatif sama besar dan bebas dari serangan hama dan penyakit. Biji ditanam sedalam 2/3 bagian berada dalam media pasir dengan posisi biji mendatar dan posisi mikropil berada pada bagian bawah, kemudian permukaan medium ditutup dengan karung goni. Media persemaian tersebut disiram pada pagi dan sore hari. 


\section{Penanaman Benih}

Benih yang telah berkecambah dengan kriteria telah mengeluarkan radikula sepanjang $1 \mathrm{~cm}$, atau berumur 3 hari kecambah dipindahkan pada media tanam (topsoil) dengan cara membuat lubang di tengah media berdiameter $1 \mathrm{~cm}$ dan kedalaman $2 \mathrm{~cm}$, kemudian tanah di sekitar perakaran dipadatkan kemudian disiram.

\section{Rancangan Penelitian}

Rancangan yang digunakan adalah Rancangan Acak Kelompok (RAK) Faktorial dengan 2 faktor, yaitu: faktor I (Pupuk $\mathrm{N}$ berasal dari urea) terdiri dari 4 taraf yaitu 0 g/polybag $\left(\mathrm{P}_{0}\right), 2 \mathrm{~g} /$ polybag $\left(\mathrm{P}_{1}\right), 4 \mathrm{~g} /$ polybag $\left(\mathrm{P}_{2}\right), 6 \mathrm{~g} /$ polybag $\left(\mathrm{P}_{3}\right)$ dan faktor II (kompos bagase) terdiri dari 4 taraf yaitu $0 \mathrm{~g} /$ polybag $\left(\mathrm{K}_{0}\right), 2 \mathrm{~g} /$ polybag $\left(\mathrm{K}_{1}\right), 4$ $\mathrm{g} /$ polybag $\left(\mathrm{K}_{2}\right)$ dan $6 \mathrm{~g} /$ polybag $\left(\mathrm{K}_{3}\right)$. Kombinasi perlakuan dapat dilihat Gambar 1 .

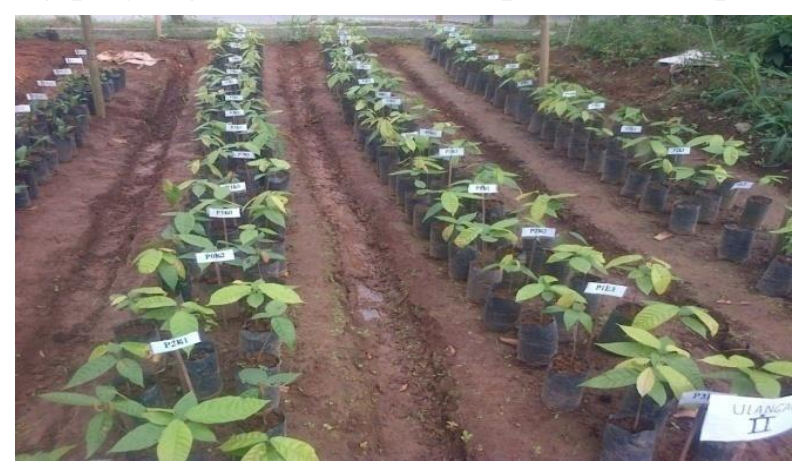

Gambar 1. Kombinasi perlakuan di lapangan

\section{Parameter dan Analisis Data}

Parameter pada penelitian ini antara lain: tinggi tanaman, jumlah dan luas daun, berat basah, dan berat kering. Tinggi tanaman diukur pada saat tanaman berumur 2, 4, 6, 8 dan 10 minggu setelah tanam (MST). Jumlah daun dilakukan dengan cara menghitung seluruh helai daun yang telah terbuka sempurna pada saat tanaman berumur 2, 4, 6, 8 dan 10 MST. Penghitungan luas daun dilaksanakan pada saat tanaman berumur 2, 4, 6, 8 dan 10 MST dengan menggunakan leaf area meter. Berat basah tanaman dilakukan dengan menimbang tanaman yang terlebih dahulu dikering anginkan pada akhir penelitian atau umur 10 MST. Berat kering dilaksanakan pada umur 10 MST dengan menimbang sudah di oven selama 3 x 24 jam pada suhu $65^{\circ} \mathrm{C}$. Semua parameter dianalisis dengan uji $\mathrm{F}$, apabila dalam uji statistik data diperoleh signifikan maka dilanjutkan dengan uji DMRT 5\% (Gomez \& Gomez, 2007).

\section{HASIL DAN PEMBAHASAN Tinggi Bibit (cm)}

Hasil sidik ragam diperoleh bahwa pemberian pupuk $\mathrm{N}$, kompos bagase, dan interaksi kedua faktor perlakuanberpengaruh tidak nyata terhadap tinggi bibit kakao mulai dari 2, 4, 6, 8, dan 10 Minggu Setelah Tanam (MST) (Tabel 1). 
Tabel 1. Uji beda rata-rata tinggi bibit tanaman $(\mathrm{cm})$ pada pemberian pupuk $\mathrm{N}$ dan kompos bagase yang berbeda serta interaksinya.

\begin{tabular}{|c|c|c|c|c|c|}
\hline \multirow{2}{*}{ Perlakuan } & \multicolumn{5}{|c|}{ Tinggi Bibit $(\mathrm{cm})$ pada umur (MST) } \\
\hline & 2 & 4 & 6 & 8 & 10 \\
\hline $\mathrm{P}_{0}$ & 16,16 & 18,57 & 22,23 & 26,08 & 31,42 \\
\hline $\mathrm{P}_{1}$ & 15,18 & 17,52 & 21,30 & 25,11 & 29,87 \\
\hline $\mathrm{P}_{2}$ & 15,94 & 18,18 & 22,68 & 26,67 & 30,69 \\
\hline $\mathrm{P}_{3}$ & 15,70 & 18,19 & 21,98 & 25,58 & 30,09 \\
\hline $\mathrm{K}_{0}$ & 15,46 & 18,30 & 22,06 & 25,88 & 29,93 \\
\hline $\mathrm{K}_{1}$ & 15,78 & 18,03 & 22,05 & 25,48 & 30,56 \\
\hline $\mathrm{K}_{2}$ & 15,88 & 17,99 & 22,56 & 26,35 & 30,66 \\
\hline $\mathrm{K}_{3}$ & 15,86 & 18,13 & 21,53 & 25,74 & 30,93 \\
\hline $\mathrm{P}_{0} \mathrm{~K}_{0}$ & 15,90 & 18,87 & 22,70 & 25,97 & 30,40 \\
\hline $\mathrm{P}_{0} \mathrm{~K}_{1}$ & 16,90 & 19,27 & 23,17 & 26,63 & 32,07 \\
\hline $\mathrm{P}_{0} \mathrm{~K}_{2}$ & 16,00 & 17,80 & 22,13 & 26,03 & 30,33 \\
\hline $\mathrm{P}_{0} \mathrm{~K}_{3}$ & 15,83 & 18,33 & 20,93 & 25,70 & 32,87 \\
\hline $\mathrm{P}_{1} \mathrm{~K}_{0}$ & 14,90 & 18,33 & 21,60 & 25,60 & 29,93 \\
\hline $\mathrm{P}_{1} \mathrm{~K}_{1}$ & 15,13 & 17,10 & 21,60 & 24,93 & 29,93 \\
\hline $\mathrm{P}_{1} \mathrm{~K}_{2}$ & 16,13 & 18,13 & 22,57 & 26,50 & 30,47 \\
\hline $\mathrm{P}_{1} \mathrm{~K}_{3}$ & 14,57 & 16,50 & 19,43 & 23,40 & 29,13 \\
\hline $\mathrm{P}_{2} \mathrm{~K}_{0}$ & 15,47 & 18,03 & 22,23 & 26,77 & 29,40 \\
\hline $\mathrm{P}_{2} \mathrm{~K}_{1}$ & 15,77 & 18,20 & 22,50 & 26,27 & 30,87 \\
\hline $\mathrm{P}_{2} \mathrm{~K}_{2}$ & 15,07 & 17,37 & 22,40 & 26,17 & 30,67 \\
\hline $\mathrm{P}_{2} \mathrm{~K}_{3}$ & 17,47 & 19,13 & 23,57 & 27,47 & 31,83 \\
\hline $\mathrm{P}_{3} \mathrm{~K}_{0}$ & 15,57 & 17,97 & 21,70 & 25,17 & 29,97 \\
\hline $\mathrm{P}_{3} \mathrm{~K}_{1}$ & 15,33 & 17,57 & 20,93 & 24,07 & 29,37 \\
\hline $\mathrm{P}_{3} \mathrm{~K}_{2}$ & 16,33 & 18,67 & 23,13 & 26,70 & 31,17 \\
\hline $\mathrm{P}_{3} \mathrm{~K}_{3}$ & 15,57 & 18,57 & 22,17 & 26,40 & 29,87 \\
\hline
\end{tabular}

Keterangan: angka-angka yang diikuti oleh huruf yang sama pada baris atau kolomyang sama menunjukan tidak berbeda nyata menurut uji rata - rata Duncan (DMRT) pada taraf $5 \%$.Pupuk $\mathrm{N}$ berasal dari urea $(\mathrm{P})$ terdiri dari $\mathrm{P}_{0}=0 \mathrm{~g} /$ polybag; $\mathrm{P}_{1}=2 \mathrm{~g} /$ polybag; $\mathrm{P}_{2}=4$ $\mathrm{g} /$ polybag, $\mathrm{P}_{3}=6 \mathrm{~g} /$ polybag.Kompos bagase $(\mathrm{K})$ terdiri dari $\mathrm{K}_{0}=0 \mathrm{~g} /$ polybag; $\mathrm{K}_{1}=2$ $\mathrm{g} /$ polybag; $\mathrm{K}_{2}=4 \mathrm{~g} /$ polybag, $\mathrm{K}_{3}=6 \mathrm{~g} /$ polybag.

Tabel 1 diperoleh bahwa pertumbuhan bibit kakao tertinggi terdapat pada pemupukan $\mathrm{N}$ dosis $0 \mathrm{~g} /$ polybag $\left(\mathrm{P}_{0}\right)$ sebesar $31,42 \mathrm{~cm}$ dan diikuti dosis $4 \mathrm{~g} /$ polybag $\left(\mathrm{P}_{2}\right)$ sebesar 30,69 $\mathrm{cm}$, dosis $6 \mathrm{~g} /$ polybag $\left(\mathrm{P}_{3}\right)$ sebesar 30,09 $\mathrm{cm}$ dan dosis $2 \mathrm{~g} /$ polybag $\left(\mathrm{P}_{1}\right)$ sebesar 29,87 cm pada akhir pengamatan (umur $10 \mathrm{MST}$ ). Pertumbuhan tinggi bibit kakao mengalami peningkatan seiring dengan peningkatan dosis kompos bagase sampai 6 g/polybag. Tinggi bibit tertinggidiperoleh pada perlakuan $K_{3}(30,39 \mathrm{~cm})$ diikuti dengan perlakuan $\mathrm{K}_{2}(30,66 \mathrm{~cm}), \mathrm{K}_{1}(30,56 \mathrm{~cm})$ dan $\mathrm{K}_{0}(29,93 \mathrm{~cm})$ di umur 10 MST serta interaksi kedua perlakuan berpengaruh tidak nyata terhadap tinggi bibit kakao dengan bibit tertinggi terdapat padainteraksi $\mathrm{P}_{0} \mathrm{~K}_{1}$ sebesar 32,07 cm di umur 10 MST.

\section{Jumlah Daun (Helai)}

Hasil sidik ragam diperoleh bahwa pemberian pupuk $\mathrm{N}$ berpengaruh nyata terhadap pertumbuhan jumlah daun bibit kakao pada umur 2 dan 4 MST, namun 
berpengaruh tidak nyata pada umur 6, 8, dan 10 MST. Pemberian kompos bagase dan interaksinya memberikan pengaruh tidak nyata jumlah daun bibit kakao pada umur 2, 4, 6, 8, dan 10 MST (Tabel 2).

Tabel 2. Uji beda rata-rata jumlah daun (helai) pada pemberian pupuk $\mathrm{N}$ dan kompos bagase yang berbeda serta interaksinya.

\begin{tabular}{cccccc}
\hline \multirow{2}{*}{ Perlakuan } & \multicolumn{5}{c}{ Jumlah Daun (helai) pada umur (MST) } \\
\cline { 2 - 6 } & 2 & 4 & 6 & 8 & 10 \\
\hline $\mathrm{P}_{0}$ & $3,36 \mathrm{~b}$ & $4,75 \mathrm{~b}$ & 6,53 & 8,50 & 11,86 \\
$\mathrm{P}_{1}$ & $3,41 \mathrm{~b}$ & $4,92 \mathrm{~b}$ & 6,78 & 8,69 & 12,36 \\
$\mathrm{P}_{2}$ & $3,72 \mathrm{a}$ & $5,00 \mathrm{a}$ & 6,56 & 8,47 & 11,44 \\
$\mathrm{P}_{3}$ & $3,92 \mathrm{a}$ & $5,39 \mathrm{a}$ & 7,08 & 8,86 & 11,47 \\
\hline $\mathrm{K}_{0}$ & 3,58 & 4,94 & 6,94 & 8,72 & 11,64 \\
$\mathrm{~K}_{1}$ & 3,55 & 4,97 & 6,89 & 8,75 & 12,08 \\
$\mathrm{~K}_{2}$ & 3,69 & 5,17 & 6,44 & 8,72 & 12,00 \\
$\mathrm{~K}_{3}$ & 3,58 & 4,97 & 6,67 & 8,33 & 11,42 \\
\hline $\mathrm{P}_{0} \mathrm{~K}_{0}$ & 3,34 & 5,00 & 6,67 & 8,56 & 11,78 \\
$\mathrm{P}_{0} \mathrm{~K}_{1}$ & 3,43 & 4,67 & 6,56 & 8,33 & 12,33 \\
$\mathrm{P}_{0} \mathrm{~K}_{2}$ & 3,22 & 4,67 & 6,33 & 8,56 & 12,22 \\
$\mathrm{P}_{0} \mathrm{~K}_{3}$ & 3,43 & 4,67 & 6,56 & 8,56 & 11,11 \\
$\mathrm{P}_{1} \mathrm{~K}_{0}$ & 3,21 & 4,89 & 6,89 & 8,67 & 12,11 \\
$\mathrm{P}_{1} \mathrm{~K}_{1}$ & 3,32 & 4,78 & 7,22 & 9,22 & 12,55 \\
$\mathrm{P}_{1} \mathrm{~K}_{2}$ & 3,66 & 5,00 & 6,44 & 8,67 & 12,33 \\
$\mathrm{P}_{1} \mathrm{~K}_{3}$ & 3,44 & 5,00 & 6,56 & 8,22 & 12,44 \\
$\mathrm{P}_{2} \mathrm{~K}_{0}$ & 3,78 & 4,78 & 6,78 & 8,78 & 11,55 \\
$\mathrm{P}_{2} \mathrm{~K}_{1}$ & 3,67 & 5,22 & 6,67 & 8,78 & 11,67 \\
$\mathrm{P}_{2} \mathrm{~K}_{2}$ & 3,88 & 5,11 & 6,11 & 8,56 & 11,89 \\
$\mathrm{P}_{2} \mathrm{~K}_{3}$ & 3,56 & 4,89 & 6,67 & 7,78 & 10,67 \\
$\mathrm{P}_{3} \mathrm{~K}_{0}$ & 4,00 & 5,11 & 7,44 & 8,89 & 11,11 \\
$\mathrm{P}_{3} \mathrm{~K}_{1}$ & 3,78 & 5,22 & 7,11 & 8,67 & 11,78 \\
$\mathrm{P}_{3} \mathrm{~K}_{2}$ & 4,00 & 5,89 & 6,89 & 9,11 & 11,56 \\
$\mathrm{P}_{3} \mathrm{~K}_{3}$ & 3,89 & 5,33 & 6,89 & 8,78 & 11,45 \\
\hline $\mathrm{K}_{2}$ & 3969 &
\end{tabular}

Keterangan: angka-angka yang diikuti oleh huruf yang sama pada baris atau kolom yang sama menunjukan tidak berbeda nyata menurut uji rata - rata Duncan (DMRT) pada taraf 5\%. Pupuk $\mathrm{N}$ berasal dari urea $(\mathrm{P})$ terdiri dari $\mathrm{P}_{0}=0 \mathrm{~g} /$ polybag; $\mathrm{P}_{1}=2 \mathrm{~g} /$ polybag; $\mathrm{P}_{2}=4$ $\mathrm{g} /$ polybag, $\mathrm{P}_{3}=6 \mathrm{~g} /$ polybag.Kompos bagase $(\mathrm{K})$ terdiri dari $\mathrm{K}_{0}=0 \mathrm{~g} /$ polybag; $\mathrm{K}_{1}=2$ $\mathrm{g} /$ polybag; $\mathrm{K}_{2}=4 \mathrm{~g} /$ polybag, $\mathrm{K}_{3}=6 \mathrm{~g} /$ polybag.

Tabel 2 menunjukkan bahwa dosis4 dan 6 g/polybag pupuk Nberdampak pada peningkatan jumlah daun bibit kakao di umur 2 dan 4 MST. Jumlah daun bibit kakao tertinggi terdapat pada perlakuan $\mathrm{P}_{3}\left(3,92\right.$ helai) yang tidak berbeda nyata dengan $\mathrm{P}_{2}$ ( 3,72 helai) namun berbeda nyata dengan $\mathrm{P}_{1}\left(3,41\right.$ helai) dan $\mathrm{P}_{0}(3,36$ helai) pada umur 2 MST. Jumlah daun bibit kakao tertinggi terdapat pada perlakuan $\mathrm{P}_{3}(5,39$ helai) yang tidak berbeda nyata dengan $\mathrm{P}_{2}\left(5,00\right.$ helai) namun berbeda nyata dengan $\mathrm{P}_{1}$ (4,92 helai) dan $\mathrm{P}_{0}$ (4,74 helai) pada umur 4 MST. Interaksi kedua perlakuan berpengaruh tidak nyata terhadap jumlah daun bibit kakao dengan jumlah daun tertinggi umur 10 MST pada perlakuan $\mathrm{P}_{1} \mathrm{~K}_{1}(12,55$ helai). 


\section{Luas Daun $\left(\mathrm{cm}^{2}\right)$}

Hasil sidik ragam diperoleh bahwa pemberian kompos bagase berpengaruh nyata terhadap luas daun bibit kakao pada umur 2-10 MST. Perlakuan pupuk $\mathrm{N}$ dan interaksinya berpengaruh tidak nyata terhadap luas daun bibit kakao pada umur 2-10 MST (Tabel 3).

Tabel 3. Uji beda rata-rata luas daun $\left(\mathrm{cm}^{2}\right)$ pada pemberian pupuk $\mathrm{N}$ dan kompos bagase yang berbeda serta interaksinya.

\begin{tabular}{|c|c|c|c|c|c|}
\hline \multirow{2}{*}{ Perlakuan } & \multicolumn{5}{|c|}{ Luas Daun $\left(\mathrm{cm}^{2}\right)$ pada umur (MST) } \\
\hline & 2 & 4 & 6 & 8 & 10 \\
\hline $\mathrm{P}_{0}$ & 74,58 & 99,39 & 116,07 & 128,69 & 154,10 \\
\hline $\mathrm{P}_{1}$ & 75,33 & 108,61 & 125,89 & 145,30 & 168,43 \\
\hline $\mathrm{P}_{2}$ & 77,75 & 107,18 & 127,54 & 143,57 & 164,67 \\
\hline $\mathrm{P}_{3}$ & 78,13 & 98,69 & 126,90 & 146,92 & 170,04 \\
\hline $\mathrm{K}_{0}$ & $95,60 \mathrm{a}$ & $135,18 \mathrm{a}$ & $151,87 \mathrm{a}$ & $181,10 \mathrm{a}$ & $208,08 \mathrm{a}$ \\
\hline $\mathrm{K}_{1}$ & $70,39 a b$ & $83,45 \mathrm{~b}$ & $114,23 b$ & $126,81 \mathrm{~b}$ & $147,06 \mathrm{~b}$ \\
\hline $\mathrm{K}_{2}$ & $71,62 \mathrm{~b}$ & $94,57 \mathrm{a} \mathrm{b}$ & $111,05 \mathrm{~b}$ & $122,24 \mathrm{~b}$ & $146,64 b$ \\
\hline $\mathrm{K}_{3}$ & $68,19 \mathrm{~b}$ & $100,69 \mathrm{~b}$ & $119,24 \mathrm{~b}$ & $134,32 \mathrm{~b}$ & $155,46 \mathrm{~b}$ \\
\hline $\mathrm{P}_{0} \mathrm{~K}_{0}$ & 73,74 & 94,04 & 109,84 & 125,97 & 145,80 \\
\hline $\mathrm{P}_{0} \mathrm{~K}_{1}$ & 73,54 & 85,07 & 105,46 & 113,96 & 131,90 \\
\hline $\mathrm{P}_{0} \mathrm{~K}_{2}$ & 77,32 & 108,41 & 122,14 & 127,40 & 168,07 \\
\hline $\mathrm{P}_{0} \mathrm{~K}_{3}$ & 73,74 & 110,05 & 126,84 & 147,42 & 170,63 \\
\hline $\mathrm{P}_{1} \mathrm{~K}_{0}$ & 100,42 & 145,47 & 162,04 & 194,96 & 225,54 \\
\hline $\mathrm{P}_{1} \mathrm{~K}_{1}$ & 72,92 & 97,58 & 113,60 & 129,75 & 151,32 \\
\hline $\mathrm{P}_{1} \mathrm{~K}_{2}$ & 79,39 & 111,25 & 127,50 & 149,11 & 172,58 \\
\hline $\mathrm{P}_{1} \mathrm{~K}_{3}$ & 48,61 & 80,15 & 100,43 & 107,37 & 124,26 \\
\hline $\mathrm{P}_{2} \mathrm{~K}_{0}$ & 109,56 & 162,96 & 181,28 & 218,30 & 246,66 \\
\hline $\mathrm{P}_{2} \mathrm{~K}_{1}$ & 60,32 & 77,22 & 99,38 & 103,45 & 119,73 \\
\hline $\mathrm{P}_{2} \mathrm{~K}_{2}$ & 65,36 & 77,63 & 94,85 & 103,99 & 120,36 \\
\hline $\mathrm{P}_{2} \mathrm{~K}_{3}$ & 75,77 & 110,90 & 134,65 & 148,56 & 171,94 \\
\hline $\mathrm{P}_{3} \mathrm{~K}_{0}$ & 98,67 & 138,23 & 154,32 & 185,16 & 214,31 \\
\hline $\mathrm{P}_{3} \mathrm{~K}_{1}$ & 74,77 & 73,92 & 138,49 & 160,10 & 185,30 \\
\hline $\mathrm{P}_{3} \mathrm{~K}_{2}$ & 64,42 & 80,98 & 99,72 & 108,48 & 125,55 \\
\hline $\mathrm{P}_{3} \mathrm{~K}_{3}$ & 74,64 & 101,65 & 115,05 & 133,94 & 155,01 \\
\hline
\end{tabular}

Keterangan: angka-angka yang diikuti oleh huruf yang sama pada baris atau kolom yang sama menunjukan tidak berbeda nyata menurut uji rata - rata Duncan (DMRT) pada taraf 5\%. Pupuk $\mathrm{N}$ berasal dari urea $(\mathrm{P})$ terdiri dari $\mathrm{P}_{0}=0 \mathrm{~g} /$ polybag; $\mathrm{P}_{1}=2 \mathrm{~g} /$ polybag; $\mathrm{P}_{2}=4$ g/polybag, $\mathrm{P}_{3}=6 \mathrm{~g} /$ polybag.Kompos bagase $(\mathrm{K})$ terdiri dari $\mathrm{K}_{0}=0 \mathrm{~g} /$ polybag; $\mathrm{K}_{1}=2$ $\mathrm{g} /$ polybag; $\mathrm{K}_{2}=4 \mathrm{~g} /$ polybag, $\mathrm{K}_{3}=6 \mathrm{~g} /$ polybag.

Tabel 3 diperoleh bahwa perlakuankompos bagase berpengaruh nyata terhadap luas daun bibit kakaodengan hasil tertinggi pada perlakuan $\mathrm{K}_{0}\left(208,08 \mathrm{~cm}^{2}\right)$ yang berbeda nyata dengan $\mathrm{K}_{2}\left(155,46 \mathrm{~cm}^{2}\right), \mathrm{K}_{3}\left(147,06 \mathrm{~cm}^{2}\right)$ dan $\mathrm{K}_{1}\left(146,64 \mathrm{~cm}^{2}\right)$.Perlakuan pupuk $\mathrm{N}$ berpengaruh tidak nyata terhadap luas daun bibit kakao dengan hasil tertinggi pada perlakuan $\mathrm{P}_{3}\left(170,04 \mathrm{~cm}^{2}\right)$ diikuti perlakuan $\mathrm{P}_{1}\left(168,43 \mathrm{~cm}^{2}\right), \mathrm{P}_{2}\left(164,67 \mathrm{~cm}^{2}\right)$ dan $\mathrm{P}_{0}\left(154,10 \mathrm{~cm}^{2}\right)$.Interaksi kedua perlakuan berpengaruh tidak nyata terhadap luas daun bibit kakao dengan perlakuan tertinggi $\mathrm{P}_{2} \mathrm{~K}_{0}\left(246,66 \mathrm{~cm}^{2}\right)$. 


\section{Berat Basah (g)}

Hasil sidik ragam diperoleh bahwa pemberian pupuk $\mathrm{N}$, kompos bagase dan interaksinya berpengaruh tidak nyata terhadap berat basah bibit kakao umur 10 MST (Tabel 4).

Tabel 4. Berat basah (g) tanaman kakao umur 10 MST pada pemberian pupuk N dan kompos bagase yang berbeda serta interaksinya.

\begin{tabular}{|c|c|c|c|c|c|}
\hline \multirow{2}{*}{$\begin{array}{l}\text { Kompos Bagase } \\
\text { (g/polybag) }\end{array}$} & \multicolumn{4}{|c|}{ Pupuk N (g/polybag) } & \multirow{2}{*}{ Rataan } \\
\hline & $\mathrm{P}_{0}$ & $\mathrm{P}_{1}$ & $\mathrm{P}_{2}$ & $\mathrm{P}_{3}$ & \\
\hline \multicolumn{6}{|c|}{ Berat Basah (g) } \\
\hline $\mathrm{K}_{0}$ & 18,75 & 14,69 & 22,38 & 16,36 & 18,05 \\
\hline $\mathrm{K}_{1}$ & 24,39 & 24,76 & 19,15 & 16,28 & 21,15 \\
\hline $\mathrm{K}_{2}$ & 23,31 & 20,17 & 27,15 & 15,75 & 21,60 \\
\hline $\mathrm{K}_{3}$ & 15,69 & 23,93 & 18,51 & 20,79 & 19,73 \\
\hline Rataan & 20,54 & 20,89 & 21,80 & 17,29 & \\
\hline
\end{tabular}

Keterangan: angka-angka yang diikuti oleh huruf yang sama pada baris atau kolom yang sama menunjukan tidak berbeda nyata menurut uji rata - rata Duncan (DMRT) pada taraf 5\%. Pupuk $\mathrm{N}$ berasal dari urea $(\mathrm{P})$ terdiri dari $\mathrm{P}_{0}=0 \mathrm{~g} /$ polybag; $\mathrm{P}_{1}=2 \mathrm{~g} /$ polybag; $\mathrm{P}_{2}=4$ g/polybag, $\mathrm{P}_{3}=6 \mathrm{~g} /$ polybag.Kompos bagase $(\mathrm{K})$ terdiri dari $\mathrm{K}_{0}=0 \mathrm{~g} / \mathrm{polybag} ; \mathrm{K}_{1}=2$ $\mathrm{g} /$ polybag; $\mathrm{K}_{2}=4 \mathrm{~g} /$ polybag, $\mathrm{K}_{3}=6 \mathrm{~g} /$ polybag.

Tabel 4 menunjukkan pemberian pupuk $\mathrm{N}$ berpengaruh tidak nyata terhadap berat basah bibit kakao dengan perlakuan tertinggi $\mathrm{P}_{2}(21,80 \mathrm{~g})$ diikuti perlakuan $\mathrm{P}_{1}(20,89 \mathrm{~g})$, $\mathrm{P}_{0}(20,54 \mathrm{~g})$ dan $\mathrm{P}_{3}$ (17,29 g).Perlakuan kompos bagase berpengaruh tidak nyata terhadap berat basah bibit kakao dengan perlakuan tertinggi $\mathrm{K}_{2}(21,60 \mathrm{~g})$ diikuti perlakuan $\mathrm{K}_{1}(21,15 \mathrm{~g}), \mathrm{K}_{3}(19,73 \mathrm{~g})$ dan $\mathrm{K}_{0}(18,05 \mathrm{~g})$.Interaksi kedua perlakuan berpengaruh tidak nyata terhadap berat basah bibit kakao dengan perlakuan tertinggi $\mathrm{P}_{2} \mathrm{~K}_{2}(27,15 \mathrm{~g})$.

\section{Berat Kering (g)}

Hasil sidik ragam diperoleh bahwa pemberian pupuk N, kompos bagase, dan interaksinya berpengaruh tidak nyata terhadap berat kering bibit kakao umur 10 MST (Tabel 5).

Tabel 5. Berat kering (g) tanaman kakao umur 10 MST pada pemberian pupuk $\mathrm{N}$ dan kompos bagase yang berbeda serta interaksinya.

\begin{tabular}{|c|c|c|c|c|c|}
\hline \multirow{2}{*}{$\begin{array}{c}\text { Kompos Bagase } \\
\text { (g/polybag) }\end{array}$} & \multicolumn{4}{|c|}{ Pupuk N (g/polybag) } & \multirow{2}{*}{ Rataan } \\
\hline & $\mathrm{P}_{0}$ & $\mathrm{P}_{1}$ & $\mathrm{P}_{2}$ & $\mathrm{P}_{3}$ & \\
\hline \multicolumn{6}{|c|}{ Berat Kering (g) } \\
\hline $\mathrm{K}_{0}$ & 12,78 & 10,01 & 15,25 & 11,15 & 12,30 \\
\hline $\mathrm{K}_{1}$ & 16,78 & 16,87 & 13,05 & 11,09 & 14,45 \\
\hline $\mathrm{K}_{2}$ & 15,88 & 13,75 & 17,38 & 10,73 & 14,44 \\
\hline $\mathrm{K}_{3}$ & 10,70 & 16,30 & 12,61 & 17,61 & 14,30 \\
\hline Rataan & 14,04 & 14,23 & 14,57 & 12,64 & \\
\hline
\end{tabular}

Keterangan: angka-angka yang diikuti oleh huruf yang sama pada baris atau kolom yang sama menunjukan tidak berbeda nyata menurut uji rata - rata Duncan (DMRT) pada taraf 5\%. Pupuk $\mathrm{N}$ berasal dari urea $(\mathrm{P})$ terdiri dari $\mathrm{P}_{0}=0 \mathrm{~g} /$ polybag; $\mathrm{P}_{1}=2 \mathrm{~g} /$ polybag; $\mathrm{P}_{2}=4$ $\mathrm{g} /$ polybag, $\mathrm{P}_{3}=6 \mathrm{~g} /$ polybag.Kompos bagase $(\mathrm{K})$ terdiri dari $\mathrm{K}_{0}=0 \mathrm{~g} /$ polybag; $\mathrm{K}_{1}=2$ $\mathrm{g} /$ polybag; $\mathrm{K}_{2}=4 \mathrm{~g} /$ polybag, $\mathrm{K}_{3}=6 \mathrm{~g} /$ polybag. 
Tabel 5 menunjukkan bahwa pemberian pupuk $\mathrm{N}$ berpengaruh tidak nyata terhadap berat kering bibit kakao dengan perlakuan tertinggi $\mathrm{P}_{2}(14,57 \mathrm{~g})$ diikuti $\mathrm{P}_{1}$ $(14,23 \mathrm{~g}), \mathrm{P}_{0}(14,04 \mathrm{~g})$ dan $\mathrm{P}_{3}(12,64 \mathrm{~g})$. Perlakuan kompos bagase berpengaruh tidak nyata terhadap berat kering bibit kakao dengan perlakuan tertinggi $\mathrm{K}_{1}(14,45 \mathrm{~g})$ diikuti perlakuan $\mathrm{K}_{2}(14,44 \mathrm{~g}), \mathrm{K}_{3}(14,30 \mathrm{~g})$ dan $\mathrm{K}_{0}(12,30 \mathrm{~g})$. Interaksi kedua perlakuan berpengaruh tidak nyata terhadap berat basah bibit kakao dengan perlakuan tertinggi $\mathrm{P}_{2} \mathrm{~K}_{2}(17,38 \mathrm{~g})$.

\section{Pembahasan}

\section{Pengaruh Kompos Bagase terhadap Tinggi Bibit Kakao}

Perlakuan kompos bagase berpengaruh tidak nyata terhadap tinggi bibit kakao. Namun jika dilihat tinggi bibit dari minggu 2, 4, 6, 8, dan 10 terdapat peningkatan tinggi bibit ini diduga karena hara yang terkandung dalam kompos bagase salah satunya unsur P. Menurut Santosa et al., (2013) meningkatnya kandungan unsur hara P dalam jaringan tanaman mempunyai peranan penting dalam pembelahan sel terutama pada perkembangan jaringan yang terus tumbuh yang berakibat lebih lanjut terhadap bertambahnya laju tinggi tanaman.

\section{Pengaruh Kompos Bagase terhadap Jumlah Daun Bibit Kakao}

Luas daun berperan penting dalam proses fotosintesis dan respirasi pada tanaman. Dalam hal ini, Perlakuan kompos bagase berpengaruh tidak nyata terhadap luas daun bibit kakao pada setiap umur tanam 2, 4, 6, 8, dan 10 MST. Sebagai bahan organik tentu penambahan kompos bagase sangat berpengaruh terhadap pertumbuhan dan perkembangan tanaman khususnya luas daun dikarenakan kadar air yang tersisa dari ampas tebu bagase masih cukup tinggi. Menurut Apriliani, (2010) ampas tebu merupakan sisa bagian batang tebu dalam proses ekstraksi tebu yang memiliki kadar air berkisar $46-52 \%$, kadar serat $43-52 \%$ dan padatan terlarut sekitar 2-6\%. Komposisi kimia ampas tebu meliputi: zat arang atau karbon (C) 23,7\%, Hidrogen (H) $2 \%$, Oksigen (O) 20\%, Air $\left(\mathrm{H}_{2} \mathrm{O}\right) 50 \%$ dan Gula 3\%.yang memiliki kadar bahan organik

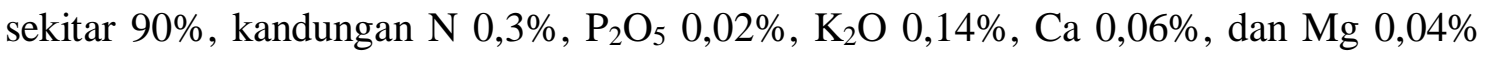
dapat memperbaiki sifat fisik tanah berupa tekstur tanah, struktur tanah dan bulk density. Peningkatan dosis pupuk berupa kompos ampas tebu terformulasi terhadap tanaman dapat memacu pertumbuhan luas daun cabai rawit (Rahimah et al., 2015).

\section{Pengaruh Kompos Bagase terhadap Bobot Basah Bibit Kakao}

Perlakuan Kompos Bagase berpengaruh tidak nyata terhadap bobot basah bibit kakao. Namun jika dilihat dari data statistik perlakuan $\mathrm{K}_{2}(4 \mathrm{~g} /$ polybag) memberikan bobot tertinggi. Kandungan $\mathrm{N}$ sebanyak 0,3\% dalam kompos bagase tentu meningkatkan pertumbuhan vegetatif tanaman khususnya batang, cabang dan daun. Peningkatan pertumbuhan vegetatif tanaman tentu akan berpengaruh terhadap bobot tanaman. Penambahan kompos juga berpengaruh terhadap perbaikan sifat fisik tanah 
yang akan menunjang pertumbuhan tanaman. Sesuai dengan penelitian Singer et al., (2008) bahwa pemberian pupuk organik dapat memacu laju pertumbuhan tanaman.

\section{Pengaruh Kompos Bagase terhadap Bobot Kering Bibit Kakao}

Bobot kering tanaman merupakan hasil representatif bobot basah tanaman. Dari data statistik dapat dilihat bahwa pemberian kompos bagase memberikan hasil tertinggi dibandingkan tanpa kompos bagase. Kandungan hara yang terkandung di dalamnya tentu memberikan dampak terhadap pertambahan bagian-bagian vegetatif tanaman. Penambahan kompos ke dalam tanah dapat memperbaiki struktur, dan lapisan tanah sehingga akan memperbaiki keadaan aerasi, drainase, absorbsi panas, kemampuan daya serap tanah terhadap air. Hal ini sejalan dengan pendapat Sutanto, (2006) bahwa bahan organik seperti kompos dapat memperbaiki sifat fisik tanah seperti struktural, aerase dan porositas tanah. Hal ini akan sangat berpengaruh terhadap pertumbuhan bibit kakao.

\section{Pengaruh Pupuk N terhadap Tinggi Bibit Kakao}

Dari data statistik dapat dilihat bahwa perlakuan $\mathrm{P}_{0}(0 \mathrm{~g} /$ polybag $)$ memberikan hasil terbaik pada 10 mst namun pada 8 mst pemberian pupuk $\mathrm{N}$ sebanyak $\mathrm{P}_{2}$ (4 $\mathrm{g} /$ polybag) menunjukkan hasil terbaik $(26,67)$. Unsur $\mathrm{N}$ merupakan unsur esensial yang diperlukan tanaman dalam pertumbuhan. Menurut Lingga \& Marsono, (2001) penambahan unsur hara nitrogen $(\mathrm{N})$ dapat merangsang pertumbuhan vegetatif yaitu cabang, batang dan daun yang merupakan komponen penyusun asam amino, protein dan pembentukan protoplasma sel sehingga dapat merangsang pertumbuhan tinggi tanaman.

\section{Pengaruh Pupuk N terhadap Jumlah daun Bibit kakao}

Perlakuan pupuk $\mathrm{N}$ berpengaruh nyata terhadap jumlah daun bibit kakao. $\mathrm{N}$ (nitrogen) berperan dalam hal pembentukan batang, daun dan bagian vegetatif lainnya. Pemberian $\mathrm{N}$ pada tanaman tentu akan memberikan dampak signifikan terhadap pertumbuhan bibit kakao. Menurut Hanafiah, (2005) penggunaan pupuk nitrogen berperan menonjol terhadap bagian vegetatif tanaman (dedaunan dan pucuk). Menurut Hakim et al., (1988) pembentukan daun oleh tanaman sangat dipengaruhi oleh ketersediaan $\mathrm{N}$, karena unsur tersebut berperan dalam pembentukan sel-sel baru dan komponen utama penyusun senyawa organik dalam tanaman seperti asam amino, asam nukleat, dan klorofil.

\section{Pengaruh Pupuk N terhadap Luas Daun Bibit Kakao}

Data statistik menunjukkan bahwa pengaruh pupuk $\mathrm{N}$ terhadap luas daun tidak nyata. Namun pemberian pupuk N 6 g/polybag menunjukkan hasil tertinggi. Unsur makro N sangat berpengaruh terhadap pertumbuhan vegetatif tanaman. Sesuai dengan Sutedjo, (2002) penambahan pupuk nitrogen juga diduga mempengaruhi lebar daun karena fungsi utama unsur $\mathrm{N}$ bagi tanaman adalah merangsang pertumbuhan tanaman khususnya batang, cabang dan daun, karena nitrogen merupakan bahan penyusun klorofil, protein, lemak, koenzim dan asam-asam nukleat. 


\section{Pengaruh Pupuk N terhadap Bobot Basah Bibit Kakao}

Pemberian pupuk N sebanyak 4 g/polybag menunjukkan hasil tertinggi. Menurut Jumin, (2002) nitrogen berfungsi untuk merangsang pertunasan dan penambahan tinggi tanaman. Sejalan dengan pendapat Lingga, (1986) menyatakan bahwa nitrogen dalam jumlah yang cukup berperan dalam mempercepat pertumbuhan tanaman secara keseluruhan, khususnya batang dan daun. Pertumbuhan bagian-bagian tanaman akan mempengaruhi bobot basah tanaman.

\section{Pengaruh Pupuk N terhadap Bobot Kering Bibit Kakao}

Sejalan dengan tingginya bobot basah dengan penambahan pupuk N (4 g/polybag) maka pada bobot kering tanaman perlakuan $\mathrm{P}_{2}(4 \mathrm{~g} /$ polybag) juga menunjukkan hasil tertinggi dibandingkan dengan perlakuan lainnya. Lakitan, (1996) menyatakan bahwa tanaman yang tidak mendapatkan tambahan nitrogen akan tumbuh kerdil serta daun terbentuk juga lebih kecil, tipis dan jumlahnya akan sedikit, sedangkan tanaman yang mendapat tambahan unsur hara nitrogen maka daun akan lebih banyak dan lebar.

\section{Interaksi Kompos Bagase dengan Pupuk N pada Bibit kakao}

Interaksi antara perlakuan pupuk $\mathrm{N}$ dan kompos bagase terbaik pada perlakuan $\mathrm{P}_{2} \mathrm{~K}_{2}$ ( $4 \mathrm{~g} /$ polybag urea dan $4 \mathrm{~g} /$ polybag kompos bagase). Nitrogen merupakan unsur hara makro yang sangat dibutuhkan tanaman dalam jumlah besar untuk menunjang pertumbuhan sehingga pemberian pupuk $\mathrm{N}$ sangat dianjurkan dalam budidaya tanaman. unsur hara $\mathrm{P}$ yang terdapat dalam kompos dan penambahan pupuk $\mathrm{N}$ berperan dalam sintesis protein, sehingga unsur $\mathrm{N}$ berpengaruh langsung terhadap penyediaan makanan dalam sel. Penambahan pupuk $\mathrm{N}$ dapat merangsang pembesaran sel dan pembelahan sel pada ujung meristem daun sehingga tumbuh daun-daun baru dan terjadi peningkatan luas daun bibit kakao (Lakitan, 1996).

\section{KESIMPULAN}

Pemberian kompos bagase berpengaruh nyata terhadap luas daun bibit kakao pada umur tanam 2 dan 4 MST. Pemberian pupuk $\mathrm{N}$ berpengaruh nyata terhadap jumlah daun bibit kakao. Interaksi perlakuan $\mathrm{P}_{2} \mathrm{~K}_{2}(4 \mathrm{~g} /$ polybag urea dan $4 \mathrm{~g} /$ polybag kompos bagase) menunjukkan berat basah dan berat kering bibit kakao tertinggi dibandingkan interaksi lainnya walaupun berpengaruh tidak nyata. .

\section{DAFTAR PUSTAKA}

Apriliani, A. (2010). Pemanfaatan arang ampas tebu sebagai adsorben ion logam Cd, $\mathrm{Cr}, \mathrm{Cu}$, dan $\mathrm{Pb}$ dalam air limbah. Skripsi. UIN Syarif Hidayatullah, Jakarta.

Arsyad, M., Sinaga, B. M., \& Yusuf, S. (2011). Analisis dampak kebijakan pajak ekspor dan subsidi harga pupuk terhadap produksi dan ekspor kakao Indonesia pasca putaran Uruguay. Jurnal Sosial Ekonomi Pertanian, 8(1), 63-71.

Dalimunthe, R. R., Irsal., \& Meiriani. (2015). Respons pertumbuhan bibit kakao (Theobroma cacao L.) terhadap pemberian pupuk organik vermikompos dan interval waktu penyiraman air pada tanah subsoil. Jurnal Online Agroekoteknologi, 3(1), 188-197. 
Direktorat Jenderal Perkebunan. (2015). Statistik perkebunan Indonesia 2014-2016. Kementerian Pertanian, Jakarta.

Gomez, K. A., \& Gomez, A. A. (1995). Prosedur statistika untuk penelitian pertanian. Terjemahan: E. Sjamsuddin \& J. S Baharsyah. UI-Press, Jakarta.

Hakim, N., Nyakpa, M. Y., Lubis, A. M., Pulung, M. A., Amrah, A. G., Munawar, A., \& Hong, G. B. (1988). Kesuburan tanah. Universitas Lampung Press, Lampung.

Hanafiah, K. A. (2005). Dasar-dasar ilmu tanah. PT Raja Grafindo Persada, Jakarta.

Jumin, H. B. (2002). Agronomi. PT. Raja Grafindo Persada, Jakarta.

Lakitan, B. (1996). Fisiologi pertumbuhan dan perkembangan tanaman. PT. Raya Grafindo Persada, Jakarta.

Lingga, P., \& Marsono. (2001). Petunjuk penggunaan pupuk. Penebar Swadaya, Jakarta.

Lingga. (1986). Petunjuk penggunaan pupuk. Penebar Swadaya, Jakarta

Marum, J., Zulfita, D., \& Maulidi. (2012). Pengaruh kompos ampas tebu terhadap pertumbuhan dan hasil tanaman lobak pada tanah podsolik merah kuning. Jurnal Sains Mahasiswa Pertanian, 2(1), 1-14. Diakses dari: https://jurnal.untan.ac.id/index.php/jspp/article/view/2427.

Musnamar, E. I. (2003). Pembuatan dan aplikasi pupuk organik padat. Penebar Swadaya, Jakarta.

Rahimah., Mardhiansyah, M., \& Yoza, D. (2015). Pemanfaatan kompos berbahan baku ampas tebu (Saccharum sp) dengan bioaktivator Trichoderma spp. sebagai media tumbuh semai Acacia crassicarpa. Jurnal Online Mahasiswa Fakultas Pertanian Universitas Riau, 2(1), 1-15.

Rosmarkam, A., \& Yuwono, N. W. (2002). Ilmu kesuburan tanah. Kanisius, Yogyakarta.

Santoso, A. C., Harwati, T., \& Siswadi. (2013). Pengaruh pemberian mikoriza arbuskula dan pupuk organik terhadap pertumbuhan bibit jati putih (Gmelina arborea Roxb.). Innofarm: Jurnal Inovasi Pertanian, 12(2), 53-66. http://dx.doi.org/10.33061/innofarm.v12i2.797.

Singer, J. W., Logsdon, S. D., \& Meek, D. W. (2008). Soybean growth and seed yield response to tillage and compost. Agronomy Journal, 100(4), 1039-1046. https://doi.org/10.2134/agronj2007.0360.

Sutanto, R. (2006). Penerapan pertanian organik. Kanisius, Yogyakarta.

Sutedjo, M. M. (2002). Pupuk dan cara penggunaan. Rineka Cipta, Jakarta. 